\title{
Morphological and Pathogenic Variations of the Causal Organisms of Leaf Twister Disease of Red Onion (Allium cepa L.) in Jaffna District of Sri Lanka
}

\author{
A. Vengadaramana* and D.M. De Costa ${ }^{1}$ \\ Postgraduate Institute of Agriculture \\ University of Peradeniya \\ Sri Lanka
}

\begin{abstract}
Leaf Twister Disease (LTD) is one of the major biotic constraints of onion cultivation in Sri Lanka. The present study was conducted to determine morphological and pathogenic variations among Colletotrichum and Fusarium isolates, causing LTD. Fungal isolates were obtained from LTD-infected onions, collected from 30 locations in the Jaffna district of Sri Lanka. The colony characters, spore dimension, colony growth rate and fungicide sensitivity in vitro and in vivo were used to determine the morphological variations of fungal isolates. Pathogenic variations of the fungal isolates in terms of pathogenicity and virulence were determined by in vivo inoculation assays using red onion (Allium cepa L.) variety Vethalan. Morphologically-different 29 isolates of Colletotrichum and 16 isolates of Fusarium were collected from different farmer fields of Jaffna district. Out of the 29 Colletotrichum isolates, six were identified as $\underline{C}$. gloeosporioides by morphological features of fungal colonies and spores. Colony and spore morphology also resembled $\underline{C}$. acutatum and $\underline{C}$. fragaria among the Colletotrichum isolates associated with the LTD infections of onion. Colony growth rate and in vivo sensitivity to fungicide (Thiophanate-methyl $50 \%+$ Thiram 30\% WP) were highly variable among the tested isolates of Colletotrichum and Fusarium. Recommended dosage of the fungicide completely inhibited the mycelia growth $\underline{\text { in }}$ vitro. However, the recommended dosage as only a single seed treatment did not completely control any isolate of Colletotrichum or Fusarium under in vivo conditions. Virulence of the Colletotrichum and Fusarium varied significantly among the isolates in terms of rapidity and extent of disease spread. The red onion variety Vethalan was not completely resistant against any isolate of the two fungal genera tested. The present study revealed that the morphological and pathogenic variations exist among different isolates of Colletotrichum and Fusarium causing LTD in red onion in Jaffna district of Sri Lanka.
\end{abstract}

Keywords: Colletotrichum spp., fusarium spp., leaf twister disease, colony and spore morphology, red onion

\section{INTRODUCTION}

Red onion (Allium cepa L.) is one of the major cash crops grown in Sri Lanka. Jaffna district accounts for nearly two thirds of the total extent of red onion cultivation in Sri Lanka (Pattie \& Wickramasinghe, 1993). It is the general practice of farmers in Jaffna peninsula to

\footnotetext{
1 Department of Agricultural Biology, Faculty of Agriculture, University Peradeniya, Sri Lanka

Corresponding author: vengad@jfn.ac.lk
} 
cultivate onion as a monoculture, repeatedly in the same farm fields throughout the year. Therefore, it provides conducive conditions for development of several economicallysignificant diseases of onion. A disorder called "Leaf twister disease" (LTD) / disco disease has been reported since 1970 as a severe threat to bulb and seed crop production of onion. Colletotrichum gloeosporioides and Fusarium oxysporum have been identified as the predominant microorganisms associated with the LTD-infected onion tissues based on morphological analyses (Weeraratne, 1997; Kuruppu, 1999). Lower part of the leaves of LTD-infected plants develop sunken pale patches which later turn into grayish coloured lesions. Leaves show twisted appearance due to this infection.

Since 1970, the disease has been reported in many onion growing regions of Sri Lanka (e.g. Trincomalee, Puttalam, Ratnapura, Matale, Anuradhapura etc.) having diverse agroecological conditions. Some pathogen populations are known to be morphologically, genetically and pathogenically diverse which occur in the process of continuous generation of novel pathogenic variations (Taylor \& Ford, 2007). Guerber et al. (2003) and Rao et al. (1998) have reported several Colletotrichum species within which having diverse morphological, pathogenic and genetic diversities. Information on pathogen diversity and geographic distribution of the pathogen populations is therefore a prerequisite for designing effective disease management practices including accurate assessment of suitable resistant germplasm in breeding programs (Abang, 2003). Gathering of information needed for effective breeding programme is very much important in case of LTD where no resistant red onion varieties are available yet. Application of fungicides is the commonly-used control measure for LTD of onion by farmers in Sri Lanka. Therefore, knowledge on sensitivity to fungicides by pathogenically different isolates will be important to design effective management practices. Identification and characterization of genera Colletotrichum and Fusarium have relied on differences in morphological features such as colony colour, size and shape of conidia and appressoria, optimal temperature for growth, growth rate and sensitivity to fungicides (Sutton, 1992; Arif et al., 2012).

The genera Colletotrichum and Fusarium contain many species comprised of endophytes, pathogens and saprophytes (Kumar \& Hyde, 2004; Photita et al., 2004; Arif et al., 2012). Therefore, accurate information on pathogenic variations is necessary for effective disease management. However, efficiency of the management of disease is doubtful as no detailed information is available on host-pathogen interactions of the disease. Hence, knowledge on the presence of different pathogenic isolates of Colletotrichum and Fusarium spp., the causal organisms of LTD and their sensitivity to fungicides will provide useful information to design effective management practices. Therefore, the objective of the study was to determine the morphological and pathogenic variations among isolates of Colletotrichum and Fusarium isolated from LTD-infected red onions collected in Jaffna district, Sri Lanka.

\section{METHODOLOGY}

\section{Isolation of pathogenic fungi}

LTD-infected red onion plant samples were collected from 30 farmer fields in Jaffna district, Sri Lanka. Causal organisms of LTD were isolated separately from bulb, leaf and pseudostem parts of the plants showing typical LTD symptoms and they were cultured on plates of Potato Dextrose Agar medium (PDA), at room temperature $\left(27 \pm 3{ }^{\circ} \mathrm{C}\right)$. Three replicates (i.e. typical symptom showing plants) per location were used for isolation of fungal pathogens. Sub culturing was done on PDA plates supplemented with ampicillin $\left(150 \mu \mathrm{gml}^{-1}\right)$ and 
streptomycin $\left(100 \mu \mathrm{gml}^{-1}\right)$ to obtain pure cultures of Colletotrichum and Fusarium isolates. Single colony isolation method was used to obtain pure cultures of Colletotrichum and Fusarium isolates.

\section{Morphological and culture characteristics}

Macroscopic features of Colletotrichum and Fusarium colonies (e.g. colour of the upper surface and reverse side, colour of the spore masses) grown on PDA were recorded. Spore shapes were observed and dimensions were measured under light microscope (x 400 magnification). Thirty spores from each fungal isolate were selected randomly and used to measure width and length, using a calibrated ocular micrometer. Rate of colony growth $(\mathrm{cm} /$ day) was calculated using colony diameter of each fungal isolate grown on PDA for seven days and growth rate was calculated as a mean of three replicates.

\section{Sensitivity to Fungicide}

Homai (Thiophanate-methyl 50\% + Thiram 30\% WP), a fungicide recommended by the Department of Agriculture, Sri Lanka and widely-used by onion farmers to control LTD was used for in vitro and in vivo assays. In the in vitro assay, recommended dosage of Homai $(1.8 \mathrm{~g} / \mathrm{l})$ was dissolved in sterile distilled water, added to molten PDA medium supplemented with ampicillin $\left(150 \mathrm{\mu gml}^{-1}\right)$ and streptomycin $\left(150 \mu \mathrm{gml}^{-1}\right)$, then mixed thoroughly by gentle shaking. From each isolate of Colletotrichum and Fusarium, a myclelial plug having diameter of $5 \mathrm{~mm}$ was placed separately on PDA medium supplemented with Homai and the antibiotics and incubated for seven days at room temperature $\left(27 \pm 3{ }^{\circ} \mathrm{C}\right)$. Each fungal isolate was replicated three times. Controls were maintained for each isolate by placing a mycelial plug on PDA medium supplemented with the antibiotics but not containing the fungicide. Radial growth of the colony was measured for each isolate grown on PDA with and without the fungicide (control). Relative inhibition of colony growth (\%) was calculated for each isolate by using the growth data values measured after seven days on control plates and plates amended with fungicides (Ivić et al., 2011). In vivo assay of fungicide sensitivity was done as a pot experiment at the Agricultural Biotechnology Centre, University of Peradeniya using red onion variety Vethalan. Onion bulbs dipped in Homai solution for $30 \mathrm{~min}(1.8 \mathrm{~g} / \mathrm{l})$ were planted in polythene bags each having diameter and height of 13 and $16 \mathrm{~cm}$, respectively. The bags were filled with sterilized soil. Ten millilitres of spore suspension of each Colletotrichum and Fusarium isolate having a spore concentration of $1 \times 10^{5}$ spores $/ \mathrm{ml}$ was added to sterilized soil prior to planting of the onion bulbs. Two sets of pots, one containing onion bulbs treated with the fungicide and another set of pots containing onion bulbs without fungicide treatment were maintained as control treatments. Pots were arranged according to a completely randomized design (CRD) with six replicates. Number of days taken to develop LTD symptoms was recorded as a measure of in vivo sensitivity to the fungicide.

\section{Pathogenic Variation}

Twenty nine isolates of Colletotrichum and 16 isolates of Fusarium were checked separately for pathogenic variation in a pot experiment at the Agricultural Biotechnology Centre, University of Peradeniya. Red onion variety Vethalan was planted at a rate of one bulb/bag in polythene bags with $13 \mathrm{~cm}$ diameter and filled with sterilized soil. Soil in one set of polythene bags was mixed with $10 \mathrm{ml}$ of spore suspension of each fungal isolate having a concentration of $1 \times 10^{5}$ conidia / ml, prior to planting bulbs of red onion. A separate set of 
polythene bags planted with onion bulbs but not inoculated with fungal spore suspension was maintained as a control treatment.

The above two types of treatments were replicated six times and arranged according to a completely randomized design. Plants were maintained in the glasshouse and Relative humidity and temperature were recorded throughout the experimental period. Number of leaves showing typical LTD symptoms out of total number of leaves of a plant and number of days taken to develop symptoms were recorded. Pathogenic variation among the isolates was determined based on disease severity in terms of percentage infected leaves of a plant and number of days taken to develop LTD symptoms.

\section{Data Analysis}

Data were analyzed by variance (ANOVA) using a SAS statistical package (version 9.1.3) and mean separation was done by Least Significance Difference (LSD). Correlation analyses were done between in vitro colony growth rate and virulence of pathogenic isolates (i.e. no. of days taken to develop symptoms and percentage infected leaves) and percentage infected leaves with number of days taken to develop symptoms.

\section{RESULTS AND DISCUSSION}

\section{Variation of colony morphology}

Twenty nine Colletotrichum isolates and 16 Fusarium isolates which were morphologically different were isolated from the LTD infected red onion samples collected from 30 different locations (Fig.s 1 and 2). Identification of Colletotrichum and Fusarium isolates was based on morphological characters such as colony characters and size and shape of conidia according to descriptions of Simmonds (1965), Smith and Black (1990) and Sutton (1992). Among the isolated fungal cultures, identification was focused on Colletotrichum and Fusarium species as $C$. gloeosporioides and $F$. oxysporum have been identified as the causal organisms of LTD (Weerarathne, 1997; Kuruppu, 1999). It is interesting to note that $70 \%$ of the Fusarium isolates were obtained from infected onion bulbs and $76 \%$ of the Colletotrichum isolates were obtained from infected leaves.

\section{Variation of spore morphology of Colletotrichum isolates}

The 29 morphologically different Colletotrichum isolates could be categorized into four groups based on the shape of the spores (Table 1). Six different Colletotrichum isolates (i.e. J09, J10, J13, J15, J23 and J24) produced straight, cylindrical larger and hayline spores, which fit well with the description of C. gloeosporioides by Sutton (1992). They also produced greyish-white colonies with dark gray to black reverse colony colour which is a common macroscopic feature of C. gloeosporioides colonies (Than et al., 2008). Eight different Colletotrichum isolates (i.e. J01, J14, J19, J29, J33, J35, J41 and J45) produced fusiform hayline spores, acute at both ends with swollen centres. Both upper and reverse surfaces of the colonies grown on PDA were white to orange in colour, with slight shades of pink and light mouse grey aerial mycelium. On the reverse side, the centre was orange to pink. The spore shape and the colony characters observed for the eight different isolates are similar to descriptions of $C$. acutatum (Živković et al., 2010). Colletotrichum acutatum is one of the most frequently reported species causing the disease commonly known as anthracnose on numerous host plants worldwide (Damm et al., 2012). Fourteen isolates of 
Colletotrichum produced very small-sized hyaline spores (range from 2.743 to $3.989 \mu \mathrm{m}$ ) which are cylindrical, straight to spindle shaped. However, it was not possible to place them at a species level based on the available information of colony and spore morphology. Isolate J18 produced spindle shaped larger spores having one end pointed and the other end rounded which can be possibly placed under the species of $C$. fragariae (Brooks, 1931).
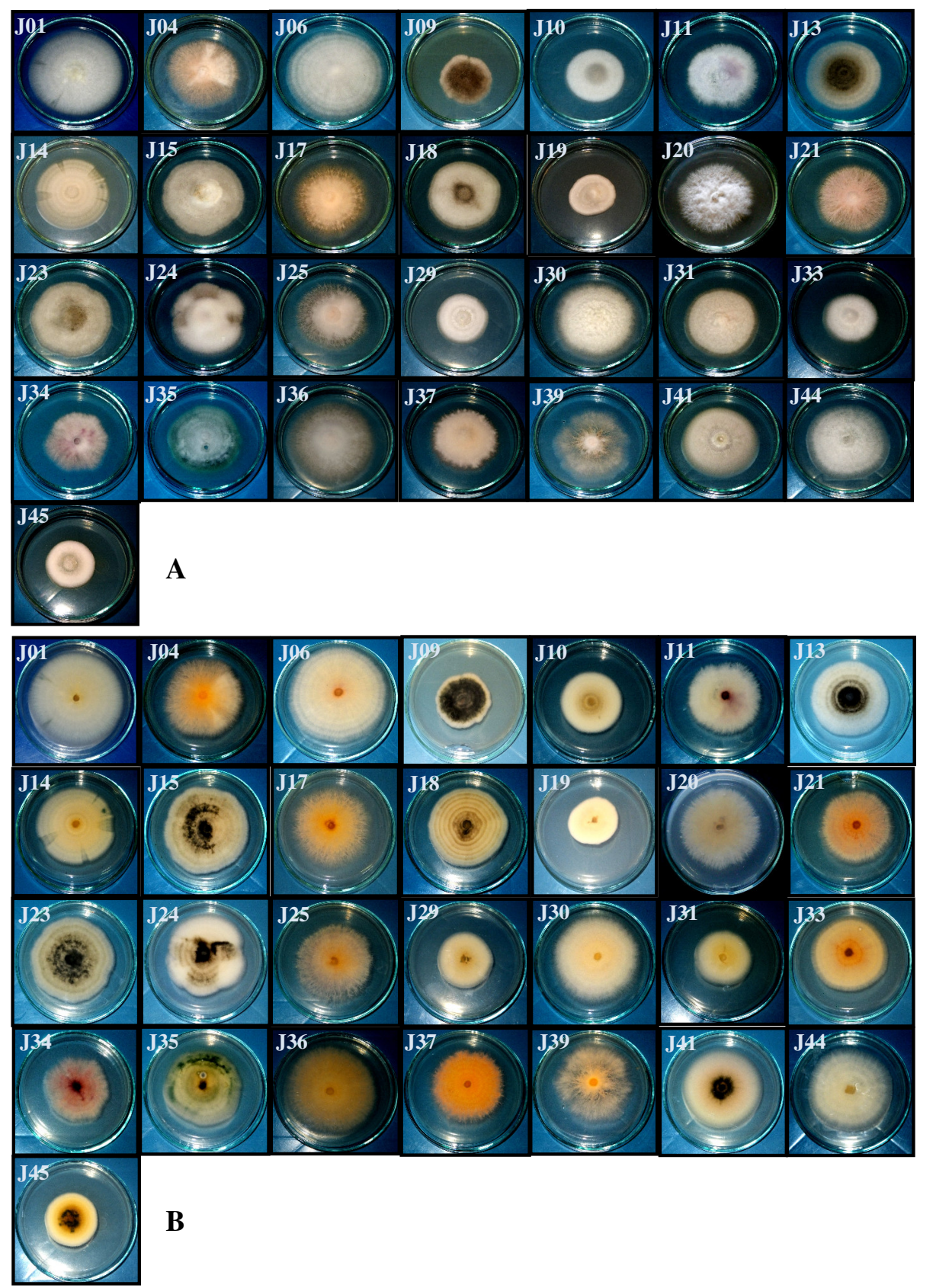

Fig. 1. Colony appearance (A: Upper side; B: Reverse side) of Colletotrichum isolates on PDA at 7 days after incubation at $27 \pm 3^{\circ} \mathrm{C}$ 


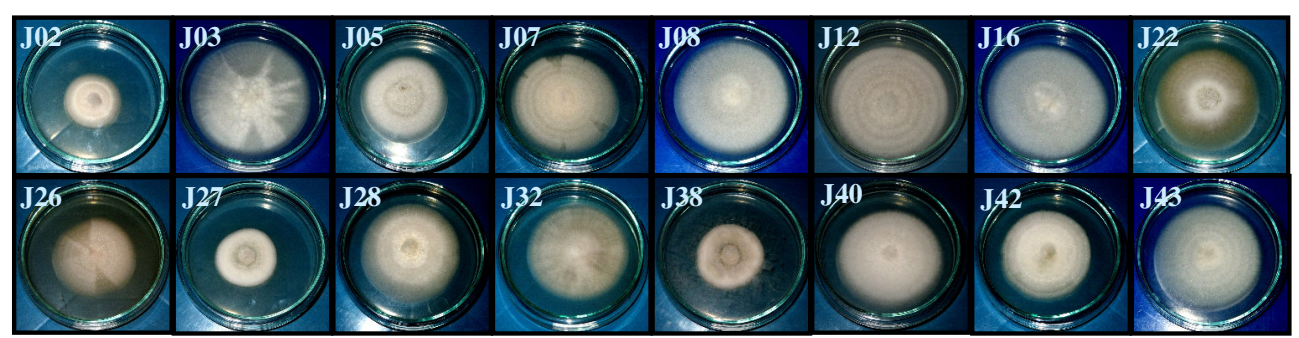

A

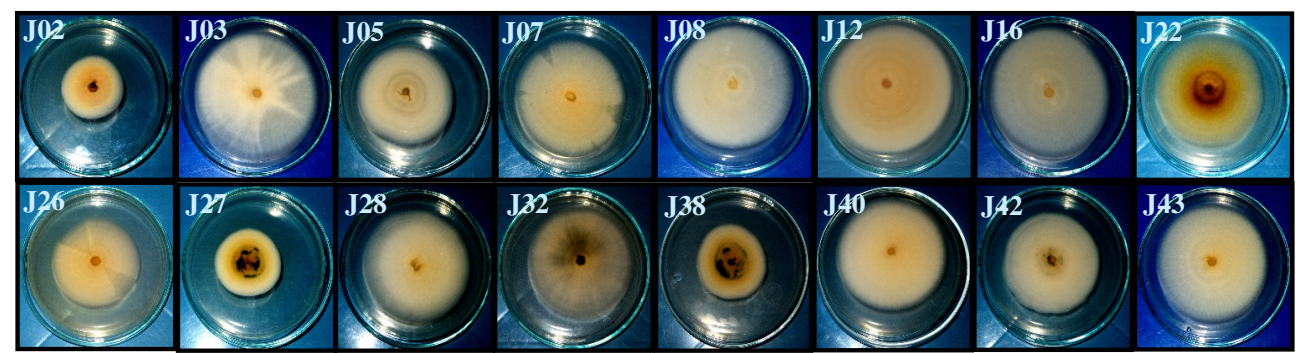

B

Fig. 2. Colony appearance (A: Upper side; B: Reverse side) of Fusarium isolates on PDA at 7 days after incubation at $27 \pm 3^{\circ} \mathrm{C}$

Table 2 gives the spore dimensions of Colletotrichum isolates when the cultures were grown on PDA. Length, width and length: width ratio of the spores differed significantly among different isolates of Colletotrichum $(\mathrm{p}<0.05)$. When the spore dimensions were considered with each group (based on spore morphology), size of conidia of group 3 isolates was (2.743 - $3.989 \times 1.056-1.965 \mu \mathrm{m})$ smaller than that of group $1(3.667-6.307 \times 2.227-3.587 \mu \mathrm{m})$, group $2(3.373-5.911 \times 1.569-2.523 \mu \mathrm{m})$ and group $4(4.253 \times 2.662 \mu \mathrm{m})$. The size of C. gloeosporioides isolated from anthracnose disease of dragon fruit was 6-10 x 2-2.5 $\mu \mathrm{m}$ (Masyahit et al., 2009). The average length of spores of C. acutatum are significantly shorter than that of the spores of $C$. gloeosporioides. However the size ranges overlapped broadly between the two species complexes (Meizhu et al., 2005).

In order to identify Colletotrichum species by morphological features, it needs some descriptive information on characters such as size and shape of conidia, conidiophores and setae in culture, size and shape of appresoria, acervuli, presence or absence of telemorphic stage. However, all these characters may vary with environmental factors and incubation conditions such as media and temperature which should be standardized for species comparison and identification (Cannon et al., 2000). In the present study conidial shape was more useful than size in determination of different groups as grouping based on spore dimensions showed overlapping results. 
Table 1. Groups of Colletotrichum isolates based on spore shapes.

\begin{tabular}{lcl}
\hline \multicolumn{1}{c}{ Isolates } & Group & \multicolumn{1}{c}{ Shape of spores } \\
$\mathrm{J} 09, \mathrm{~J} 10, \mathrm{~J} 13$, & 1 & $\begin{array}{l}\text { Cylindrical, straight. One or } \\
\text { both ends are pointed. Hyaline. } \\
\text { Unicellular. }\end{array}$
\end{tabular}

J01, J14, J19, J29, J33, J35, J41, J45

J04, J06, J11, $\mathrm{J} 17, \mathrm{~J} 20, \mathrm{~J} 21$, $\mathrm{J} 25, \mathrm{~J} 30, \mathrm{~J} 31$, $\mathrm{J} 34, \mathrm{~J} 36, \mathrm{~J} 37$, $\mathrm{J} 39, \mathrm{~J} 44$

J18

2
Fusiform. Acute at both ends. The center is swollen. Hyaline. Unicellular.

3

Very small in size. Cylindrical; straight to spindle shaped. Hyaline, Unicellular.

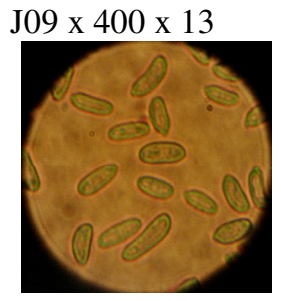

J14 x 400x 13

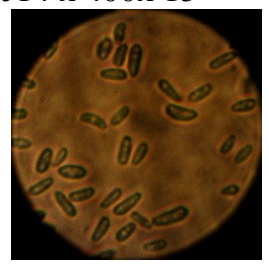

$\mathrm{J} 20 \times 400 \times 13$

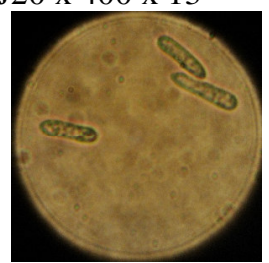

$\mathrm{J} 18 \times 400 \times 13$

\section{Variation of spore morphology of Fusarium isolates}

Fusarium isolates were grouped into two, based on the type of spores, namely the isolates producing slightly curved macro conidia with 2-3 cells and isolates producing micro conidia with no or one speta (Table 3). Out of the 19 Fusarium isolates, except J02 and J32 all the others produced both macro and micro conidia (Table 3 ).

All Fusarium isolates except isolates $\mathrm{J} 02$ and $\mathrm{J} 32$ produced one type of macroconidia which are sickle shaped, pointed at ends and 3-5 celled. Microconidia were abundant, cylindrical and 1-2 celled. These conidial characters represent Fusarium oxysporum according to description given by Nelson et al. (1983). They also produced white to pink mycelia. Faint purplish pigment was apparent when cultures were viewed from the underside. 
Table 2. Spore dimensions of Colletotrichum isolates grown on PDA 7 days after incubation at $27 \pm 3{ }^{\circ} \mathrm{C}$

\begin{tabular}{|c|c|c|c|c|}
\hline \multirow{2}{*}{ Group } & \multirow{2}{*}{ Isolates } & \multicolumn{3}{|c|}{ Conidial Dimensions } \\
\hline & & $\begin{array}{l}\text { Mean Length } \\
(\mu \mathrm{m})\end{array}$ & $\begin{array}{l}\text { Mean Width } \\
(\mu \mathrm{m})\end{array}$ & $\begin{array}{l}\text { Mean Length / } \\
\text { Width }\end{array}$ \\
\hline 1 & J09 & $4.929^{\mathrm{fde}}$ & $1.789^{\mathrm{feg}}$ & $2.760^{\mathrm{dc}}$ \\
\hline 1 & $\mathrm{~J} 10$ & $5.605^{\text {bdac }}$ & $2.112^{\mathrm{b}}$ & $2.644^{\text {gdfce }}$ \\
\hline 1 & $\mathrm{~J} 13$ & $6.307^{\mathrm{a}}$ & $1.760^{\text {fheg }}$ & $3.583^{\mathrm{a}}$ \\
\hline 1 & $\mathrm{~J} 15$ & $5.133^{\mathrm{dec}}$ & $1.613^{\mathrm{hi}}$ & $3.255^{\mathrm{ba}}$ \\
\hline 1 & $\mathrm{~J} 23$ & $4.576^{\mathrm{feg}}$ & $2.053^{\mathrm{cb}}$ & $2.344^{\text {gdfhe }}$ \\
\hline 1 & $\mathrm{~J} 24$ & $3.667^{\mathrm{jihk}}$ & $1.628^{\mathrm{hi}}$ & $2.227^{\text {gihj }}$ \\
\hline 2 & J01 & $5.251^{\text {bdec }}$ & $1.907^{\mathrm{ced}}$ & $2.771^{\mathrm{dc}}$ \\
\hline 2 & $\mathrm{~J} 14$ & $4.385^{\text {fhg }}$ & $1.672^{\text {hig }}$ & $2.698^{\mathrm{dce}}$ \\
\hline 2 & J19 & $3.373^{\text {njmlk }}$ & $1.628^{\mathrm{hi}}$ & $2.089^{\mathrm{ihj}}$ \\
\hline 2 & J29 & $3.972^{\text {jihg }}$ & $1.951^{\mathrm{cd}}$ & $2.089^{\mathrm{ihj}}$ \\
\hline 2 & $\mathrm{~J} 33$ & $5.911^{\text {ba }}$ & $2.112^{\mathrm{b}}$ & $2.84^{\mathrm{bc}}$ \\
\hline 2 & $\mathrm{~J} 35$ & $3.975^{\text {jihg }}$ & $1.569^{\mathrm{i}}$ & $2.601^{\text {gdfce }}$ \\
\hline 2 & $\mathrm{~J} 41$ & $5.573^{\mathrm{bdc}}$ & $2.039^{\mathrm{cb}}$ & $2.738^{\mathrm{de}}$ \\
\hline 2 & $\mathrm{~J} 45$ & $5.661^{\text {bac }}$ & $2.523^{\mathrm{a}}$ & $2.272^{\text {gifhe }}$ \\
\hline 3 & J04 & $3.667^{\mathrm{jihk}}$ & $1.687^{\text {hig }}$ & $2.171^{\mathrm{ihj}}$ \\
\hline 3 & J06 & $2.875^{\mathrm{nml}}$ & $1.276^{\mathrm{kj}}$ & $2.283^{\text {gifhe }}$ \\
\hline 3 & $\mathrm{~J} 11$ & $2.743^{\mathrm{n}}$ & $1.056^{\mathrm{m}}$ & $2.667^{\mathrm{dfce}}$ \\
\hline 3 & $\mathrm{~J} 17$ & $2.889^{\mathrm{nml}}$ & $1.393^{\mathrm{j}}$ & $2.391^{\text {gdfhe }}$ \\
\hline 3 & $\mathrm{~J} 20$ & $3.396^{\mathrm{njmlk}}$ & $1.569^{\mathrm{i}}$ & $2.367^{\text {gdfhe }}$ \\
\hline 3 & $\mathrm{~J} 21$ & $2.966^{\mathrm{nmlk}}$ & $1.731^{\text {fhg }}$ & $1.801^{\mathrm{j}}$ \\
\hline 3 & $\mathrm{~J} 25$ & $3.696^{\mathrm{jihk}}$ & $1.848^{\mathrm{fed}}$ & $2.033^{\mathrm{ihj}}$ \\
\hline 3 & $\mathrm{~J} 30$ & $3.857^{\text {jihg }}$ & $1.349^{\mathrm{kj}}$ & $2.908^{\mathrm{bc}}$ \\
\hline 3 & $\mathrm{~J} 31$ & $2.845^{\mathrm{nm}}$ & $1.100^{\mathrm{ml}}$ & $2.667^{\mathrm{dfce}}$ \\
\hline 3 & $\mathrm{~J} 34$ & $3.582^{\mathrm{jilk}}$ & $1.965^{\mathrm{cbd}}$ & $1.867^{\mathrm{ij}}$ \\
\hline 3 & $\mathrm{~J} 36$ & $3.989^{\text {jihg }}$ & $1.760^{\text {fheg }}$ & $2.266^{\text {gifh }}$ \\
\hline 3 & $\mathrm{~J} 37$ & $3.491^{\mathrm{jmlk}}$ & $1.232^{1}$ & $2.912^{\mathrm{bc}}$ \\
\hline 3 & J39 & $3.403^{\mathrm{njmlk}}$ & $1.247^{\mathrm{kjl}}$ & $2.745^{\mathrm{dc}}$ \\
\hline 3 & $\mathrm{~J} 44$ & $3.916^{\mathrm{jihg}}$ & $1.364^{\mathrm{kj}}$ & $2.944^{\mathrm{bc}}$ \\
\hline 4 & J18 & $4.253^{\text {fihg }}$ & $1.613^{\mathrm{hi}}$ & $2.662^{\mathrm{dfce}}$ \\
\hline
\end{tabular}

Means in columns followed by same letter are not significantly different by LSD at $5 \%$ level 
Table 3. Groups of Fusarium isolates based on spore morphology

\begin{tabular}{|c|c|c|c|}
\hline Isolates & Group & \multicolumn{2}{|c|}{ Type of conidia } \\
\hline \multirow[t]{2}{*}{$\mathrm{J} 02, \mathrm{~J} 32$} & 1 & Micro conidia. & \\
\hline & & & $\mathrm{J} 02 \times 400 \times 13$ \\
\hline \multirow{6}{*}{$\begin{array}{l}\mathrm{J} 03, \mathrm{~J} 05, \mathrm{~J} 07, \\
\mathrm{~J} 08, \mathrm{~J} 12, \mathrm{~J} 16, \\
\mathrm{~J} 22, \mathrm{~J} 26, \mathrm{~J} 27, \\
\mathrm{~J} 28, \mathrm{~J} 38, \mathrm{~J} 40, \\
\mathrm{~J} 42, \mathrm{~J} 43\end{array}$} & 2 & Micro and macro & \\
\hline & & conidia & \\
\hline & & & \\
\hline & & & \\
\hline & & & \\
\hline & & & $\mathrm{J} 42 \times 400 \times 13$ \\
\hline
\end{tabular}

Tan or orange sporodochia were abundant and the frequent occurrence of blue sclerotia in culture was visible (Caesar, 1996). Microconidia were of $6.86-2.112 \times 8.272-1.936 \mu \mathrm{m}$ dimensions and macroconidia were of $11.352-2.598 \times 4.664-2.024 \mu \mathrm{m}$ dimensions (Table 4). James et al. (2000) reported that some isolates of Fusarium oxysproum were highly virulent, whereas others were nonpathogenic fungi. More-over, both highly virulent isolates and nonpathogenic isolates are not morphologically different.

\section{Variation of colony growth rate}

Growth rates showed a significant difference among Colletotrichum and Fusarium isolates $(\mathrm{P}<0.0001)$. All Colletotrichum isolates exhibited a growth rate $>1.163 \mathrm{~cm} /$ day and $\mathrm{J} 01$ and J36 showed the highest growth rate (Fig. 3). The lowest growth rate was shown by isolate J19. However, the growth rate did not have a strong bias to a particular group of Coleltotrichum separated as in the Fig. 3. All Fusarium isolates exhibited a growth rate of $>$ $0.646 \mathrm{~cm} /$ day and J03 showed the highest growth rate (Fig. 4). The lowest growth rate was shown by isolates J02, J27 and J38. The faster growth of fungal colonies could be an indicator that the respective isolate has the capability to colonize host tissues faster than the fungal isolates having slower growth rates.

Such a positive correlation between growth rate of the fungus and virulence has been identified with fungal pathogens such as Ophiostoma ulmi and Fusarium spp. (Brasier and Webber, 1987; Brennan et al., 2003). Similarly, negative relationships between in vitro colony growth rate and virulence of fungal isolates have been reported (Brasier and Webber, 1987, Brennan et al., 2003, Irzykowska \& Bocianowski, 2008). 
Table 4. Spore dimensions of Fusarium isolates grown on PDA 7 days after incubation at $27 \pm 3{ }^{\circ} \mathrm{C}$

\begin{tabular}{|c|c|c|c|c|c|c|c|}
\hline \multirow{2}{*}{ Group } & \multirow{2}{*}{ Isolates } & \multicolumn{3}{|c|}{ Macro conidia } & \multicolumn{3}{|c|}{ Micro conidia } \\
\hline & & $\begin{array}{l}\text { Mean } \\
\text { Length } \\
(\mu \mathrm{m})\end{array}$ & $\begin{array}{l}\text { Mean } \\
\text { Width } \\
(\mu \mathrm{m})\end{array}$ & $\begin{array}{l}\text { Mean } \\
\text { Length / } \\
\text { Width }\end{array}$ & $\begin{array}{l}\text { Mean } \\
\text { Length } \\
(\mu \mathrm{m})\end{array}$ & $\begin{array}{l}\text { Mean } \\
\text { Width } \\
(\mu \mathrm{m})\end{array}$ & $\begin{array}{l}\text { Mean } \\
\text { Length / } \\
\text { Width }\end{array}$ \\
\hline 1 & $\mathrm{~J} 02$ & - & - & - & $5.4560^{\text {ed }}$ & $2.024^{\mathrm{ba}}$ & $2.72^{\mathrm{bdc}}$ \\
\hline 1 & $\mathrm{~J} 32$ & - & - & - & $6.86^{\mathrm{ba}}$ & $2.024^{\text {ba }}$ & $3.43^{\mathrm{a}}$ \\
\hline 2 & $\mathrm{~J} 03$ & $10.912^{\text {bac }}$ & $2.112^{\text {ed }}$ & $5.3567^{\mathrm{a}}$ & $5.72^{\mathrm{dc}}$ & $1.936^{\mathrm{ba}}$ & $2.98^{\mathrm{bac}}$ \\
\hline 2 & $\mathrm{~J} 05$ & $10.384^{\mathrm{bdc}}$ & $2.42^{\text {bal }}$ & $4.381^{\mathrm{edc}}$ & $5.72^{\mathrm{dc}}$ & $2.068^{\mathrm{ba}}$ & $2.9318^{\mathrm{bac}}$ \\
\hline 2 & J07 & $8.8^{\mathrm{fg}}$ & $2.2^{\mathrm{edc}}$ & $4.0^{\mathrm{fe}}$ & $5.544^{\mathrm{edc}}$ & $2.024^{\mathrm{ba}}$ & $2.7^{\mathrm{bdc}}$ \\
\hline 2 & J08 & $10.032^{\text {del }}$ & $2.068^{\mathrm{ed}}$ & $4.9^{\mathrm{bac}}$ & $6.512^{\text {bac }}$ & $2.112^{\text {ba }}$ & $3.08^{\mathrm{bac}}$ \\
\hline 2 & $\mathrm{~J} 12$ & $8.272^{\mathrm{g}}$ & $2.244^{\mathrm{edc}}$ & $3.7233^{\mathrm{f}}$ & $5.456^{\mathrm{ed}}$ & $2.112^{\text {ba }}$ & $2.6667^{\mathrm{dc}}$ \\
\hline 2 & $\mathrm{~J} 16$ & $9.768^{\mathrm{de}}$ & $2.024^{\mathrm{e}}$ & $4.85^{\mathrm{bac}}$ & $5.896^{\mathrm{bdc}}$ & $1.936^{\mathrm{ba}}$ & $3.08^{\mathrm{bac}}$ \\
\hline 2 & $\mathrm{~J} 22$ & $10.032^{\mathrm{dec}}$ & $2.64^{\mathrm{a}}$ & $3.7999^{\mathrm{f}}$ & $4.664^{\mathrm{e}}$ & $2.112^{\mathrm{ba}}$ & $2.25^{\mathrm{d}}$ \\
\hline 2 & J26 & $10.296^{\mathrm{bdc}}$ & $2.112^{\text {ed }}$ & $4.9867^{\mathrm{ba}}$ & $5.632^{\mathrm{edc}}$ & $1.98^{\mathrm{ba}}$ & $2.8933^{\mathrm{bc}}$ \\
\hline 2 & $\mathrm{~J} 27$ & $9.24^{\mathrm{fe}}$ & $2.2^{\text {edc }}$ & $4.21^{\text {fed }}$ & $4.928^{\mathrm{ed}}$ & $1.892^{\mathrm{b}}$ & $2.6^{\mathrm{dc}}$ \\
\hline 2 & $\mathrm{~J} 28$ & $10.296^{\mathrm{bdc}}$ & $2.288^{\mathrm{bdc}}$ & $4.5567^{\mathrm{bdc}}$ & $5.544^{\mathrm{edc}}$ & $1.892^{\mathrm{b}}$ & $2.95^{\mathrm{bac}}$ \\
\hline 2 & $\mathrm{~J} 38$ & $10.56^{\mathrm{bdac}}$ & $2.2^{\mathrm{edc}}$ & $4.8^{\mathrm{bc}}$ & $7.04^{\mathrm{a}}$ & $2.2^{\mathrm{a}}$ & $3.2 b^{\mathrm{a}}$ \\
\hline 2 & $\mathrm{~J} 40$ & $11.352^{\mathrm{a}}$ & $2.598^{\mathrm{ba}}$ & $4.5401^{\text {bedc }}$ & $5.632^{\mathrm{edc}}$ & $1.936^{\text {ba }}$ & $2.92^{\mathrm{bac}}$ \\
\hline 2 & $\mathrm{~J} 42$ & $10.56^{\mathrm{bdac}}$ & $2.2^{\mathrm{edc}}$ & $4.85^{\mathrm{bac}}$ & $5.632^{\mathrm{edc}}$ & $1.892^{\mathrm{b}}$ & $2.97^{\mathrm{bac}}$ \\
\hline 2 & $\mathrm{~J} 43$ & $11.088^{\mathrm{ba}}$ & $2.376^{\mathrm{bc}}$ & $4.7067^{\mathrm{bdc}}$ & $5.808^{\mathrm{dc}}$ & $2.024^{\mathrm{ba}}$ & $2.9133^{\mathrm{bac}}$ \\
\hline
\end{tabular}

Means in columns followed by same letter are not significantly different by LSD at $5 \%$ level

In the present study with the Colletotrichum and Fusarium isolates tested, neither significant positive nor negative correlation was found between the in vitro colony growth rate and the aggressiveness/virulence of the fungal isolates in terms of the percentage infected leaves or no. of days taken to develop symptoms in vivo. The reason may be the fungal isolates which have high growth rate in the artificial media sometimes fail to grow and colonize under harsh in vivo conditions.

\section{Sensitivity to Fungicide and in vivo}

In vitro screening revealed that the growth of all isolates of Colletotrichum and Fusarium was completely inhibited (100 \%) by Homai (Thiophanate-methyl 50\% WP + Thiram 30\% WP) when supplemented with PDA medium at the rate of $1.8 \mathrm{~g} / \mathrm{L}$. Since the fungicidal effect can be changed under real in-plant conditions due to three way interactions of host-pathogen and environment, the fungicide was tested in vivo in terms of no. of days taken to develop LTD symptoms. There was a very high significant variation on in vivo fungicide sensitivity among Colletotrichum $(\mathrm{P}<0.0039)$ and Fusarium isolates $(\mathrm{p}<0.0004)$. 


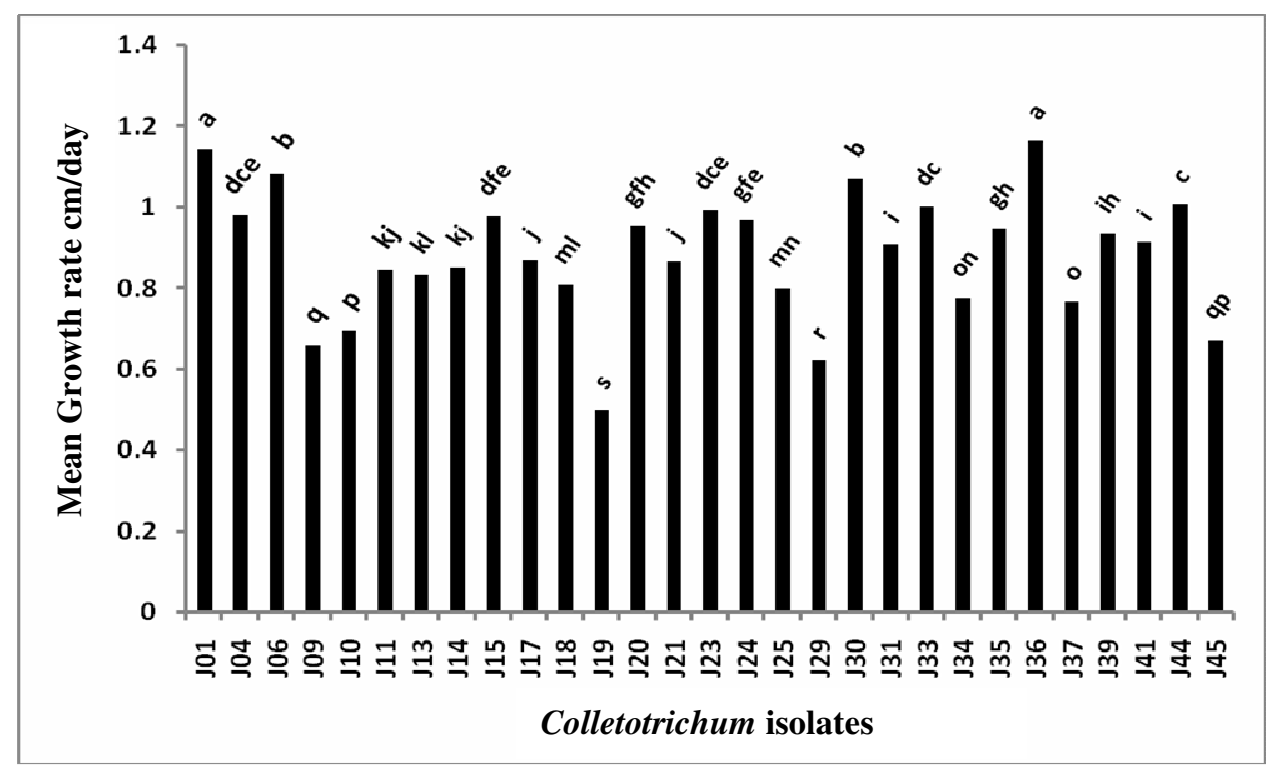

Means followed by same letter are not significantly different by LSD at 5\% level

Fig. 3. Colony growth rate of Colletotrichum isolates on PDA medium

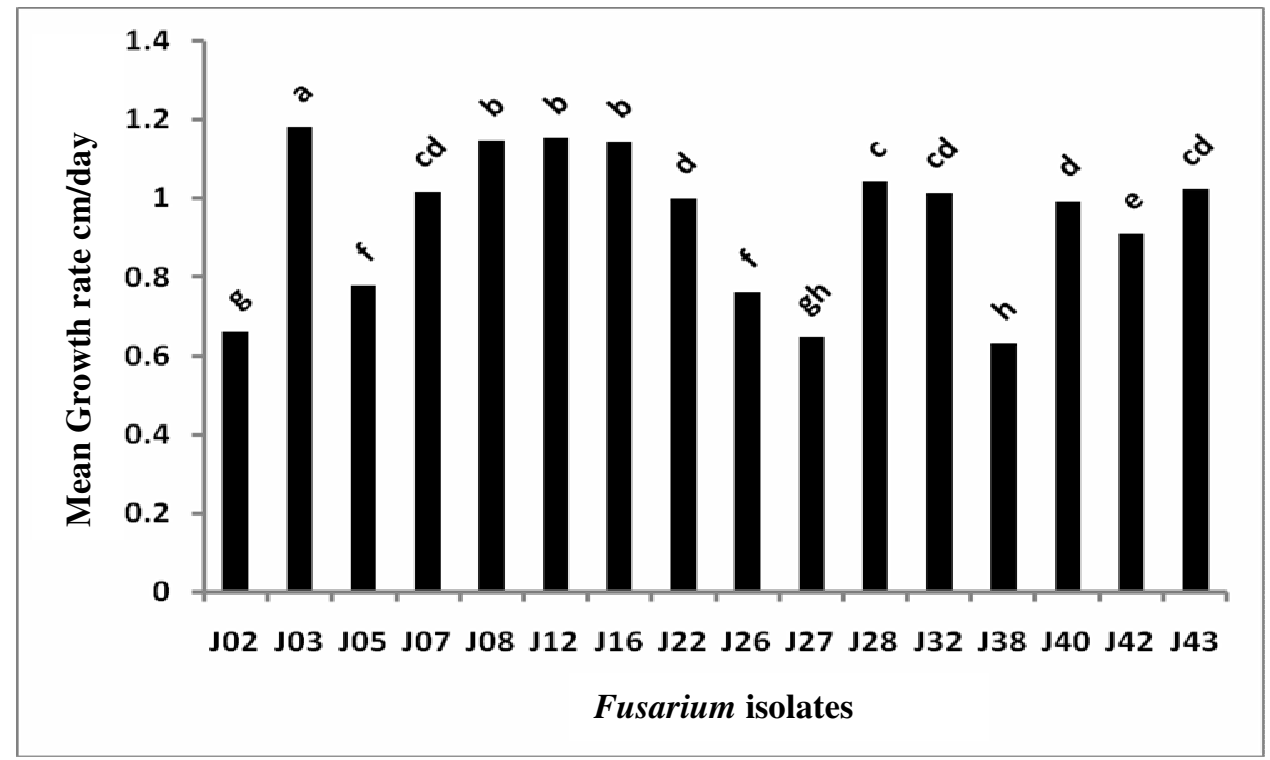

Means followed by same letter are not significantly different by LSD at 5\% level

Fig. 4. Colony growth rate of Fusarium isolates on PDA medium

It is clear that all isolates of both genera were not completely controlled by the recommended dosage of Homai when applied as a dip treatment of onion bulbs (Fig. 5 and 6), even though a complete inhibition of all isolates of the both genera was given under in vitro conditions. 
No. of days taken to develop LTD symptoms varied from $48-21$ for the tested Colletotrichum isolates.

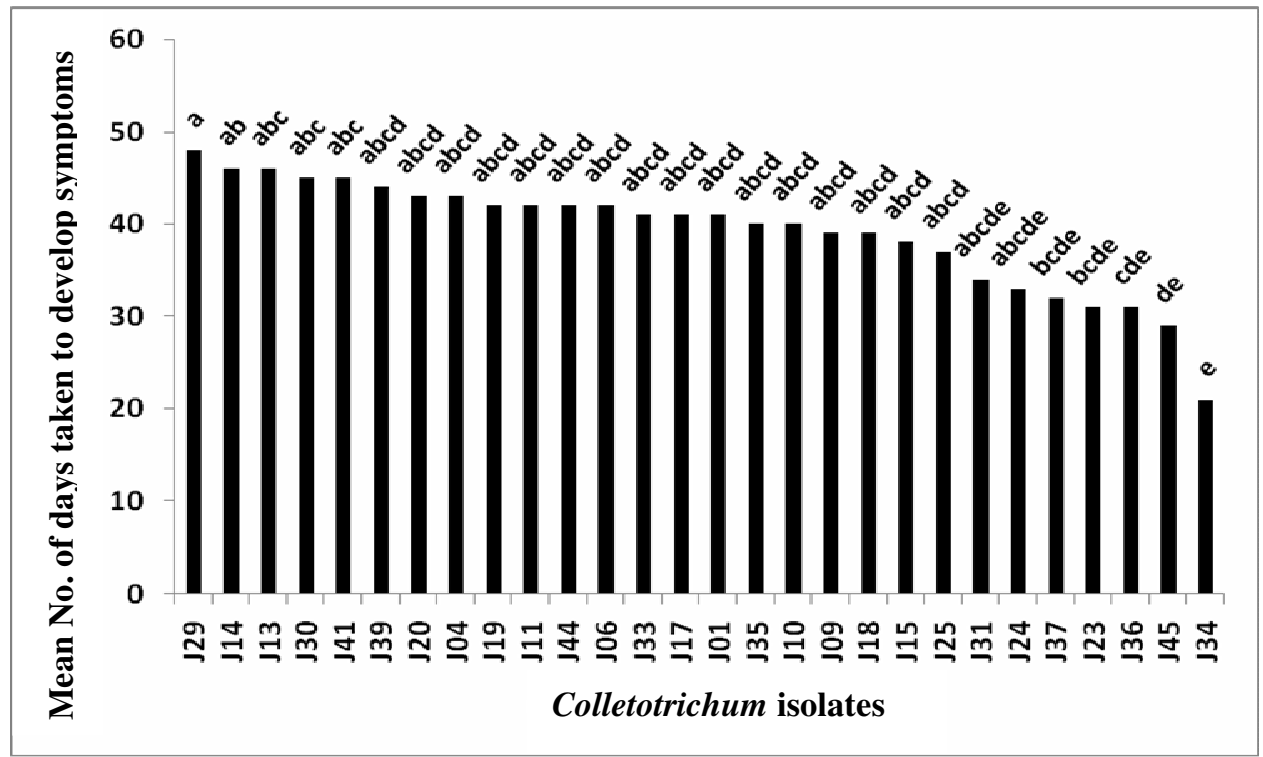

Means followed by same letter are not significantly different by LSD at $5 \%$ level

Fig. 5. No. of days taken to develop LTD symptoms by different Colletotrichum isolates when inoculated on red onion variety Vethalan

Accordingly, isolates J34 and J29 showed the least sensitivity and highest sensitivity respectively, to the fungicide treatment under in vivo condition. Therefore, with reference to isolate $\mathrm{J} 29$, isolate $\mathrm{J} 34$ is 2.28 times quicker in developing the disease. Similar to Colletotrichum isolates, none of the Fusarium isolates were completely inhibited by only a single seed treatment of fungicide prior to planting under in vivo condition. Two sets of control plants showed no symptoms development (i.e. one set containing onion bulbs treated with the fungicide and another set of pots containing onion bulbs without fungicide treatment were maintained as control treatments). Among Fusarium isolates, the no. of days taken to show symptoms varied between 46 to 23 days. Isolate $\mathbf{J} 28$ showed the longest number of days (46) and J27 showed the shortest number of days (23). Symptom development of isolates $\mathbf{J} 28, \mathbf{J} 26, \mathrm{~J} 38$ and $\mathbf{J} 43$ took twice longer time than that of the isolate $\mathbf{J} 27$. The effect of a fungicide in vitro may not reflect the efficacy of the product under practical conditions. Cultivar response, temperature, persistence of fungicides on plant organs, sensitivity of fungal spores to fungicides, extent of translocation of different systemic fungicidal compounds are some of the factors which affect on the performance and efficacy of fungicides under field conditions (Jones, 2000; Simpson et al., 2001; Pirgozliev et al., 2002).

Reaction of a fungal strain or an isolate to a certain fungicidal compound is a phenotypic characteristic which is always variable in populations of plant pathogenic fungi (Ivić et al., 2011). Differences in fungicide sensitivity among species of the same genus have been reported by many researchers for a range of fungal pathogens including Phythium, Fusarium, Colletotrichum and Phytophthora (Elmer, 1996; Simpson et al., 2001; Brantner \& Windels, 1998; Holmes \& Eckert, 1999; Tarnowski et al., 2003). Experiments conducted using 76 
isolates of Pythium ultimum var. sporangiiform, P. aphanidermatum using 21 isolates and Penicillium digitatum using 18 isolates have revealed the differences in sensitivity to fungicides imazalil, thiabendazole and o-phenylphenyl (Brantner and Windels, 1998; Holmes and Eckert, 1999; Tarnowski et al., 2003). Having a larger number of pathogen isolates with varying degree of fungicide sensitivity poses a threat to development of fungicide resistance and reduces the efficiency of a management programme based on fungicides.

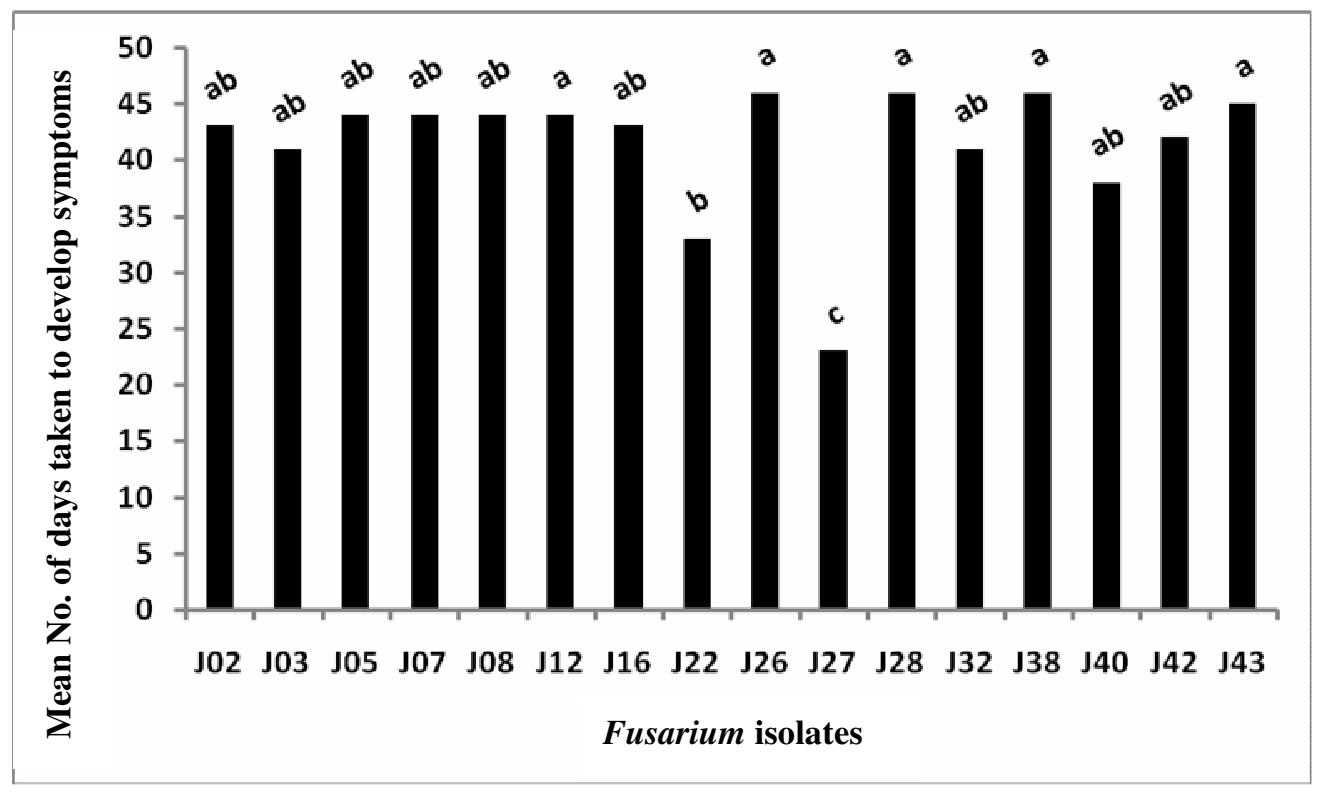

Means followed by same letter are not significantly different by LSD at 5\% level

Fig. 6. No. of days taken to develop LTD symptoms by different Fusarium isolates when inoculated on red onion variety Vethalan

\section{Pathogenic variation}

Characteristic symptoms of LTD were developed at different intensities by all the isolates of Colletotrichum and Fusarium on onion plants at different days after inoculation of the pathogen. Plants inoculated with Colletotrichum isolates showed initial twisting of leaves followed by chlorosis and abnormal elongation of the pseudostem. The plants resulted in very poor bulb formation. Plants inoculated with Fusarium isolates showed slight twisting, wilting and chlorosis of leaves and abnormal elongation of the pseudostem followed by bulb rotting. Percentage infected leaves varied among Colletotrichum and Fusarium isolates significantly $(\mathrm{p}<0.0001$ and $\mathrm{p}<0.001$, respectively)

The highest percentage of infected leaves among Colletotrichum isolates were reported by isolates J37. Isolates J06, J09, J10, J11, J15, J17, J23, J24, J30, J31, J36, J37 and J44 were not significantly different in terms of percentage of infected leaves. Isolate J33 gave the lowest percentage of infected leaves on inoculated onion plants (Fig. 7). The days taken to develop LTD symptoms vary among Colletotrichum isolates $(\mathrm{p}<0.01)$. The isolates taking higher number of days show a slower rate of disease development. 


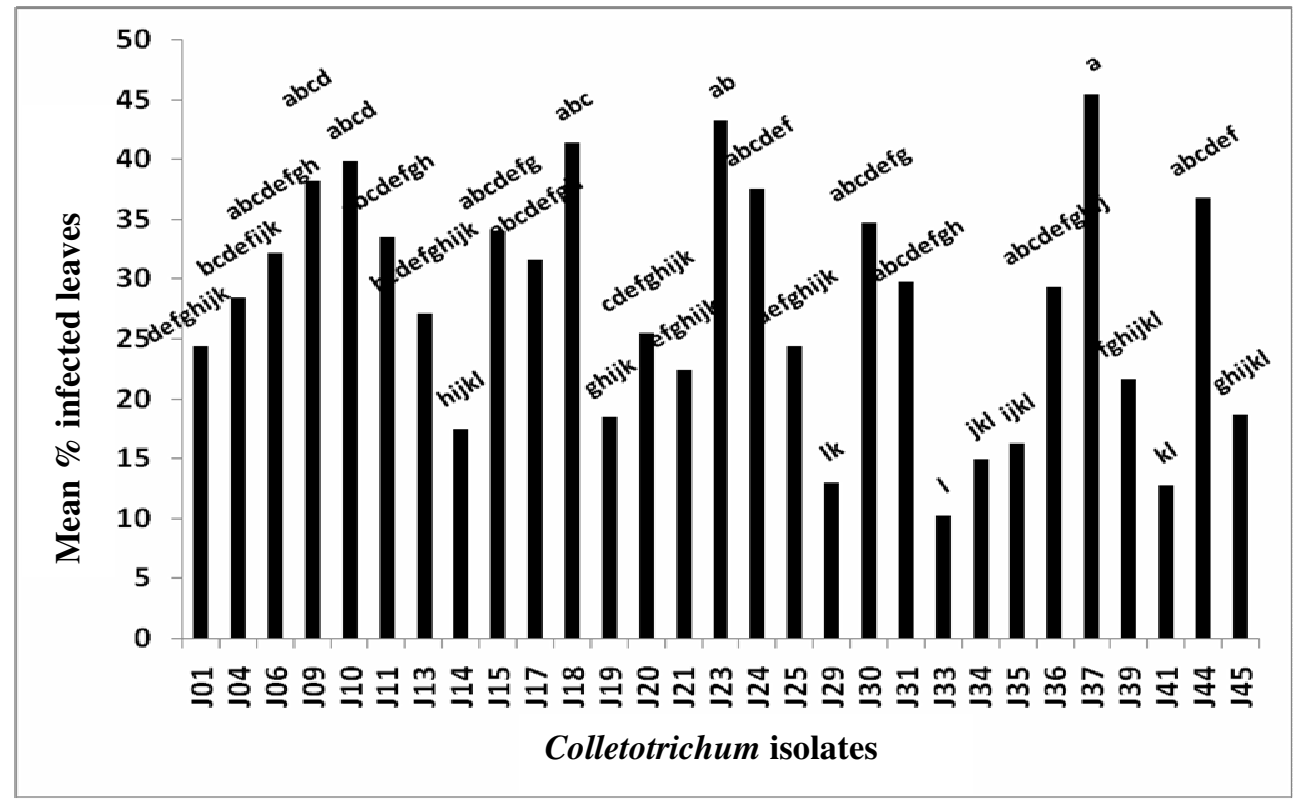

Means followed by same letter are not significantly different by LSD at 5\% level

Fig. 7. Virulence of different Colletotrichum isolates in terms of \% leaves infected on red onion variety Vethalan

Accordingly, isolate J34 and J19 took a longer time to develop symptoms hence have a slower disease development (Fig. 8). The lowest number of days was taken by the isolates J09, J10, J15 and J23; hence, a rapid development of symptoms was observed. However, the isolates showing higher number of infected leaves are not identical to the isolates showing lowest number of days to develop symptoms. Therefore, it is clear that the different Colletotrichum isolates behave differently in terms of the number of leaves affected and the speed of disease development. In general, isolates J34, J19, J35 and J29 are less virulent on variety Vethalan in terms of the amount of disease caused and the rate of disease development.

However, a significant negative relationship (43.3\%) was identified between the percentage infected leaves and the number of days taken to develop LTD symptoms for the Colletotrichum isolates tested $(\mathrm{p}<0.0186)$. Above observations clearly showed that variety Vethalan did not show complete resistance to any of the Colletotrichum isolates tested (Fig.s 7 and 8). According to definition by Taylor et al. (2007) and Taylor and Ford (2007), the variations of quantitative measurements on disease development provide an idea of the diverse nature of the pathogen population in terms of their aggressiveness i.e. natural variation in virulence.

The level of aggressiveness of isolates of a given pathogen is also an important consideration in resistance breeding programmes and disease control management. Host genotypes with partial resistance would result in lower level of infection which eventually will decrease the inoculum amount in the field to limit the potential of epidemics (Than et al., 2008). 


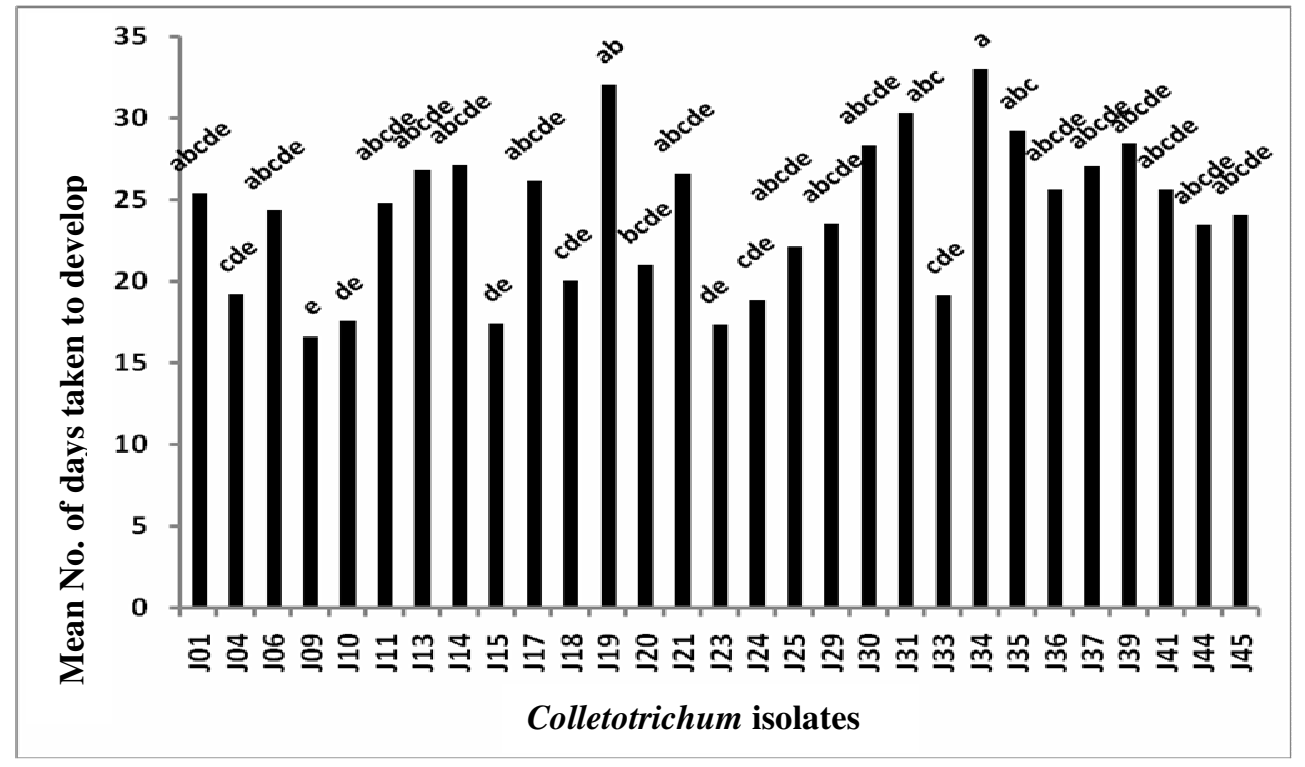

Means followed by same letter are not significantly different by LSD at $5 \%$ level

Fig. 8. Virulence of different Colletotrichum isolates in terms of number of days taken to develop symptoms on red onion variety Vethalan

Percentage of infected leaves differ significantly among the inoculated Fusarium isolates $(\mathrm{p}<0.0011)$ (Fig. 9) while no significant difference was observed among the isolates on the days taken to develop LTD symptoms (Fig. 10). The highest percentage of infected leaves was shown by Fusarium isolate J32 followed by J02, J07 and J08. The lowest percentage of infected leaves was reported by isolate J43. Even though there was no significant difference among the Fusarium isolates on the no. of days taken to develop symptoms, the quickest disease development was shown by isolates $\mathrm{J} 22$, J27 and J40 according to the lowest number of days taken for the disease development. The lowest disease development was shown by the isolates J26, J38 and J42. Accordingly, pathogenic behaviour of the Fusarium isolates can be considered highly diverse. Some of the Fusarium isolates showed higher aggressiveness in terms of the quickness of disease development while the others were aggressive in terms of the percentage infected leaves.

Findings of the present study revealed the variation of aggressiveness of different Colletotrichum and Fusarium isolates when determined by two different disease assessment methods (e.g. percentage infected leaves and no. of days taken to develop symptoms). This is in agreement with the results reported by many researchers on comparative virulence of isolates of a range of fungal pathogens, to name a few, Colletotrichum coccodes causing black dot disease of potato (Daami-Remadi et al., 2010), C. gloeosporioides causing anthracnose of yam (Abang et al., 2001) and C. graminicola causing sorghum anthracnose (Rao et al., 1998). Results of the present study identified the presence of several isolates of Colletotrichum and Fusarium within one of the onion-growing regions of Sri Lanka, the differential response of those isolates to currently-used fungicide and the variation of virulence of different isolates of the two fungal pathogens. Such biological and pathological 
information would be highly useful to modify chemical-based management measures and develop crop improvement programmes for LTD pathosystem.

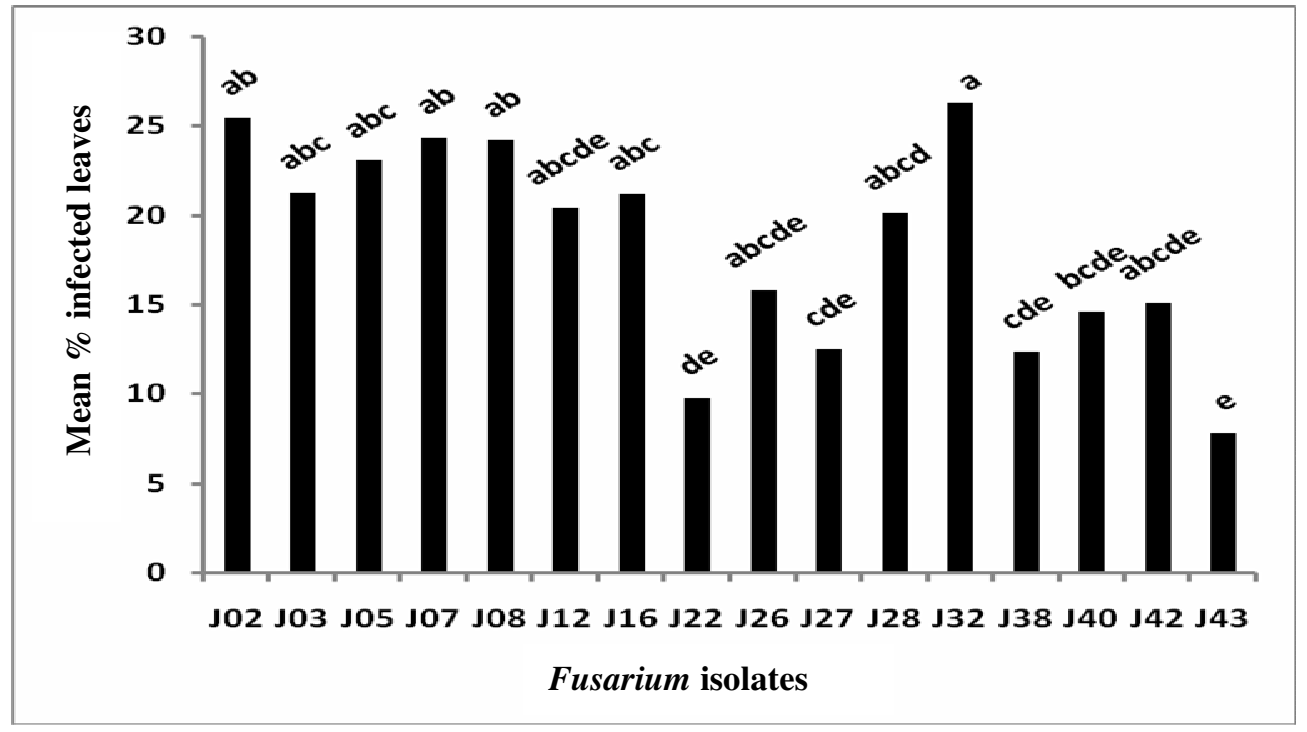

Means followed by same letter are not significantly different by LSD at 5\% level

Fig. 9. Virulence of different Fusarium isolates in terms of \% leaves infected on red onion variety Vethalan

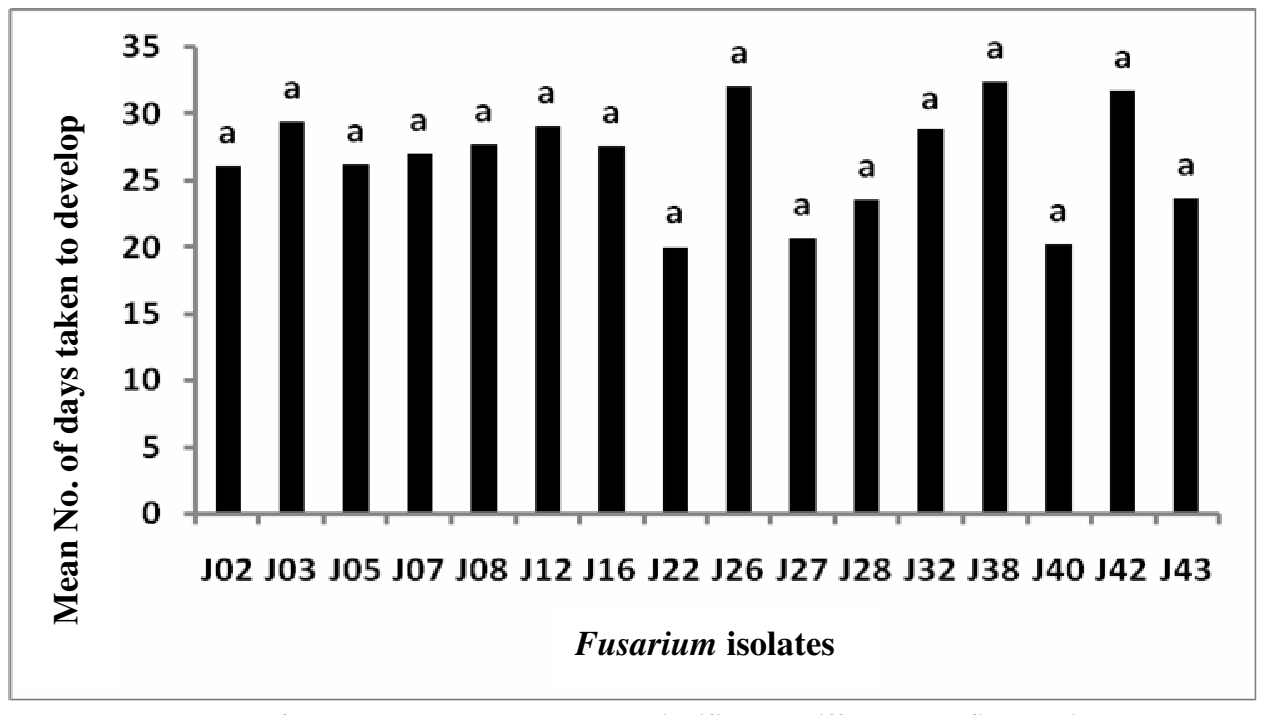

Means followed by same letter are not significantly different by LSD at $5 \%$ level

Fig. 10. Virulence of different Fusarium isolates in terms of number of days taken to develop symptoms on red onion variety Vethalan 


\section{CONCLUSION}

The present study revealed that morphological and pathogenic variations exist among different isolates of Colletotrichum and Fusarium infecting red onion in Jaffna district of Sri Lanka.

\section{ACKNOWLEDGMENT}

Financial assistance by University Grants Commission, Sri Lanka is acknowledged.

\section{REFERENCES}

Abang, M.M. (2003). Genetic diversity of Colletotrichum gloeosporioides Penz. causing anthracnose disease of yam (Dioscorea spp.) in Nigeria. Bibliotheca Mycologia, 197, 20-33.

Abang, M.M., Green, K.R., Wanyera, N.W. and Iloba, C. (2001). Characterization of Colletotrichum gloeosporioides Penz. from yam (Dioscorea spp.) in Nigeria. In: Akoroda AO, Ngeve JM. (Eds), Root Crops in the 21st Century. Proceedings of the 7th Triennial Symposium of the International Society for Tropical Root Crops-Africa Branch, Cotonou, Be'nin, 613-615.

Arif, M., Chawla, S., Zaidi, N.W., Rayar, J.K., Variar, M. and Singh, U.S. (2012). Development of specific primers for genus Fusarium and $F$. solani using rDNA sub-unit and transcription elongation factor (TEF-1 $\alpha$ ) gene. African Journal of Biotechnology, 11(2), 444447.

Brantner, J.R. and Windels, C.E. (1998). Variability in sensitivity to metalaxyl in vitro, pathogenicity, and control of Pythium spp. on sugar beet. Plant Disease, 82, 896-899.

Brasier, C.M. and Webber, J.F. (1987). Positive correlations between in vitro growth rate and pathogenesis in Ophiostoma ulmi. Plant Pathology, 36, 462-466.

Brennan, J.M., Fagan, B., Van Maanen, A., Cooke, B.M. and Doohan, F.M. (2003). Studies on in vitro growth and pathogenicity of European Fusarium fungi. European Journal of Plant Pathology, 109, 577-587.

Brooks, A.N. (1931). Anthracnose of strawberry caused by Colletotrichum fragariae n. sp. Phytopathology, 21, 739-744.

Caesar, A.J. (1996). Identity, pathogenicity, and comparative virulence of Fusarium spp. related to stand declines of leafy spurge (Euphorbia esula) in northern plains. Plant Disease, 80(12), 1395-1398.

Cannon, P.F., Bridge, P.D. and Monte, E. (2000). Linking the past present and future of Colletttrichum systematics. In: Prusky, D., Freeman, S. and Dickman, M.B., (Eds.) Colletotrichum host specificity, pathology and host pathogen interaction. APS press, St Paul, Minnesota: 1-20. 
Daami-Remadi, M., Bouallegue, R., Jabnoun-Khiareddine, H. and Mahjoub, E.M. (2010). Comparative aggressiveness of Tunisian Colletotrichum cocodes isolates on potato Assessed via Black Dot severity, plant growth and yield loss. Pest Technology, 4(1), 45-53.

Damm, U., Cannon, P.F., Woudenberg, J.H.C. and Crous, P.W. (2012). The Colletotrichum acutatum species complex. Studies in Mycology, 73, 37-113.

Elmer, W.H. (1996). Fusarium fruit rot of pumpkin in Connecticut. Plant Disease, 80, 131135 .

Guerber, J.C., Liu, B., Correll, J.C. and Johnston, P.R. (2003). Characterization of diversity in Colletotrichum acutatum sensu lato by sequence analysis of two gene introns, mtDNA and intron RFLPs, and mating compatibility. Mycologia, 95, 872-895.

Holmes, G.J. and Eckert, J.W. (1999). Sensitivity of Penicillium digitatum and P. italicum to postharvest citrus fungicides in California. Phytopathology, 89, 716-721.

Irzykowska, L. and Bocianowski, J. (2008). Genetic variation, pathogenicity and mycelial growth rate differentiation between Gaeumannomyces graminis var. tritici isolates derived from winter and spring wheat. Annals of Applied Biology, 152, 369-375.

Ivić, D., Sever, Z. and Kuzmanovska, B. (2011). In vitro sensitivity of Fusarium graminearum, $F$. avenaceum and $F$. verticillioides to carbendazim, tebuconazole, flutriafol, metconazole and prochloraz. Pesticide and Phytomedicine, 26(1), 35-42.

James, R.L., Perez, R., Dumroese, R.K. and Wenny, D.L. (2000). Virulence of Fusarium oxysporum on Douglas-fir germinants: comparison of isolates from nursery soil and roots of healthy and diseased seedlings. Lilja, A. and J. R. Sutherland, (Eds) Proceedings of the fourth Meeting of IUFRO Working Party 7.03-04 (Disease and Insects in Forest Nurseries). Research Paper 781. Finish Forest Reseach Institutute, Research paper 781. pp. 49-64.

Jones, R.K. (2000). Assessments of Fusarium head blight of wheat and barley in response to fungicide treatment. Plant Disease, 9, 1021-1031.

Kumar, D.S.S. and Hyde, K.D. (2004). Biodiversity and tissue recurrence of endophytic fungi in Tripterygium wilfordii. Fungal Diversity. 17, 69-90.

Kuruppu, K.U. (1999). First report of Fusarium oxysporum causing a leaf twisting disease on Allium cepa var. ascalonicum in Sri Lanka. Plant Disease, 83(7), 695-698.

Masyahit, M., Sijam, K., Awang, Y. and Mohd Satar, M.G. (2009). The First report of the occurance of Anthracnose disease caused by Colletotrichum gloeosporioides (Penz.) Penz \& Sacc. On Dragon Fruit (Hylocereus spp.) in Peninsular Malaysia. American Journal of Applied Sciences, 6(5), 902-912.

Meizhu, D., Schardl, C.L., Nuckles, E.M. and Vaillancourt, L.J. (2005). Using mating-type gene sequences for improved phylogenetic resolution of Colletotrichum species complexes. Mycologia, 97(3), 641-658.

Nelson, P.E., Toussoun, T.A., Marasas, W.F.O. (1983). Fusarium species: An illustrated manual for identification. Pennsylvania. Stated of University press, University Park. pp193. 
Pattie, S.P. and Wickremasinghe, Y.M. (1993). Present status and future prospects of onion production in Sri Lanka. Department of Agriculture, Peradeniya, Sri Lanka.

Photita, W., Lumyong, S., Lumyong, P., Mckenzie, E.H.C. and Hyde, K.D. (2004). Are some endophytes of Musa acuminata latent pathogens?. Fungal Diversity, 16, 131-140.

Pirgozliev, S.R., Edwards, S.G., Hare, M.C. and Jenkinson, P. (2002). Effect of dose rate of azoxystrobin and metconazole on the development of Fusarium head blight and the accumulation of deoxynivalenol (DON) in wheat grain. European Journal of Plant Pathology, $108,469-478$.

Rao, V.P., Thakur, R.P. and Mathur, K. (1998). Morphological and pathogenic diversity among grain sorghum isolates of C. gramanicola in India. Indian Phytopathology, 51(2), 164-174.

Simmonds, J.H. (1965). A study of the species of Colletotrichum causing ripe fruit rots in Queensland. Queensl. Journal of Agricultural Animal Sciences, 22, 437-459.

Simpson, D.R., Weston, G.E., Turner, J.A., Jennings, P. and Nicholson, P. (2001). Differential control of head blight pathogens of wheat by fungicides and consequences for mycotoxin contamination of grain. European Journal of Plant Pathology, 107, 421-431.

Smith, B.J. and Black, L.L. (1990). Morphological, cultural and pathogenic variation among Colletotrichum species isolated from strawberry. Plant Disease, 74, 69-76.

Sutton, B.C. (1992). The genus Glomerella and its anamorph Colletotrichum. In: Colletotrichum:biology, pathology and control (Eds. J.A. Bailey and M.J. Jeger). CAB International, Wallingford: 1-26.

Tarnowski, T., Batzer, J., Gleason, M., Helland, S. and Dixon, P. (2003). Sensitivity of newly identified clades in the sooty blotch and flyspeck complex on apple to thiophanatemethyl and ziram. [On line]. [Accessed on 10.08. 20013] Available at http://www.plantmanagementnetwork.org/pub/php /research/2003/apple/

Taylor, P.W.J. and Ford, R. (2007). Diagnostics, Genetics diversity and pathogenic variation of ascochyta blight of cool season food and feed legumes. European Journal of Plant Pathology, 127-133.

Taylor, P.W.J., Mongkolporn, O., Than, P.P., Montri, P., Ranathunge, N., Kanchanaudonkarn, C., Ford, R., Pongsupasamit, S. and Hyde, K.D. (2007). Pathotypes of Colletotrichum spp. Infecting Chilli Peppers and Mechanisms of Resistance. In: Oh, D.G., Kim, K.T. (Eds.), Abstracts of the First International Symposium on Chilli Anthracnose. National Horticultural Research Institute, Rural Development of Administration, Republic of Korea, p.29.

Than, P.P., Jeewon, R., Hyde, K.D., Pongsupasamit, S., Mongkolporn, O. and Taylor, P.W.J. (2008). Characterization and pathogenicity of Colletotrichum species associated with anthracnose disease on chilli (Capsicum spp.) in Thailand. Plant Pathology, 57(3), 562-572. 
Weeraratne, G.W.A.P. (1997). Leaf twister disease of onion (Allium cepa L.). Tropical Agriculturist. 151, 25-33.

Živković, S., Stojanović, S., Ivanović, Z., Trkulja, N., Dolovac, N., Aleksić, G. and Balaž, J. (2010). Morphological and Molecular Identification of Colletotrichum acutatum from Tomato Fruit. Pestic. Phytomed (Belgrade), 25(3), 231-239. 